Original Research Paper

\title{
Penyuluhan Tentang Mitigasi Bencana Tsunami Berbasis Hutan Mangrove Di Desa Ketapang Raya Kecamatan Keruak Lombok Timur
}

\author{
Didik Santoro $^{1 *}$, M. Yamin ${ }^{1}$, Muh. Mahrus ${ }^{2}$ \\ ${ }^{1}$ Program Studi Pendidikan Biologi Fakultas Keguruan dan Ilmu Pendidikan, Universitas Mataram \\ ${ }^{2}$ Program Studi Pendidikan Fisika Fakultas Keguruan dan Ilmu Pendidikan, Universitas Mataram
} *Corresponding Author:
Didik Santoso, Program
Studi Pendidikan Biologi
Fakultas Keguruan dan
Ilmu Pendidikan,
Universitas Mataram,
Indonesia;
Email:
didik_santoso@unram.ac.id

\begin{abstract}
Abstrak: Kejadian bencana selalu menimbulkan banyak kerugian baik jiwa maupun materi, karena kurangnya kewaspadaan dan kesiapan masyarakat dalam menghadapi ancaman bahaya. Bencana gempa bumi yang terjadi disertai dengan tsunami mengakibatkan wilayah pesisir rusak. Di lain sisi, wilayah pesisir Indonesia termasuk padat dengan permukiman dan pembangunan. Pulau Lombok merupakan salah satu pulau terbesar di Provinsi Nusa Tenggara Barat (NTB) juga memiliki tingkat kerawanan yang tinggi terhadap bencana tsunami. Hal ini dikarenakan bagian selatan Pulau Lombok berhadapan langsung dengan Samudra Hindia yang merupakan pertemuan dua lempeng benua yaitu lempeng Benua Asia dan lempeng Benua Australia. Kejadian tsunami di daerah Lunyuk Sumbawa bagian selatan pada tahun 1979 juga berdampak pada daerah-daerah selatan Pulau Lombok yaitu daerah kawasan teluk Tanjung Luar di Kecamatan Keruak dan daerah kawasan Teluk Awang di Lombok Tengah. Dalam rangka mengurangi bahaya tsunami, dan sekaligus untuk melindungi wilayah pesisir dari ancaman abrasi, angin laut, penyusupan air asin ke arah daratan, menyerap bahan pencemar, serta mempertahankan produktivitas pantai dan laut, perlu dilakukan pelestarian dan perlindungan hutan mangrove ataupun hutan pantai. Mangrove adalah suatu komunitas tumbuhan atau suatu individu jenis tumbuhan yang membentuk komunitas tersebut di daerah pasang surut. Hutan mangrove adalah tipe hutan yang secara alami dipengaruhi oleh pasang surut air laut, tergenang pada saat pasang naik dan bebas dari genangan pada saat pasang rendah. Ekosistem mangrove adalah suatu sistem yang terdiri atas lingkungan biotik dan abiotik yang saling berinteraksi di dalam suatu habitat mangrove. "Mangrove" adalah vegetasi hutan yang tumbuh di antara garis pasang surut. Karena karakter pohon mangrove yang khas, ekosistem mangrove berfungsi sebagai peredam gelombang dan badai, pelindung abrasi, penahan lumpur, dan perangkap sedimen. Disamping itu, ekosistem mangrove juga merupakan penghasil detritus dan merupakan daerah asuhan (nursery ground), daerah untuk mencari makan (feeding ground), serta daerah pemijahan (spawning ground) bagi berbagai jenis ikan, udang, dan biota laut lainnya. Juga sebagai pemasok larva ikan, udang, dan sebagai tempat pariwisata.
\end{abstract}

Kata Kunci: Mangrove, Mitigasi, Tsunami

\section{Pendahuluan}

Indonesia merupakan negara maritim terbesar di dunia yang memiliki laut terluas (3,9 juta $\mathrm{km})$, pulau terbanyak (17.508 buah), dan terpanjang ke-2 di dunia setelah Kanada (81.000 km). Namun seperti yang disampaikan Diposaptono dan Budiman (2005), kondisi ini harus diwaspadai, karena kawasan maritim Indonesia merupakan daerah yang secara tektonik sangat labil, selain bahwa kawasan ini juga terkenal sebagai salah satu pinggiran benua yang sangat aktif di muka bumi. Selain itu, Indonesia juga memiliki kekayaan gunung berapi, setidaknya dari 240 buah sekitar 70 diantaranya masih aktif. Dalam pemetaan gempa, wilayah pesisir Indonesia termasuk rawan terhadap bahaya tsunami. Ismail (1982) dan Kertapati (1991) dalam Diposaptono dan Budiman (2005), telah 
menetapkan sekitar 89 daerah rawan tsunami yang tersebar di seluruh Indonesia, mulai dari barat Pulau Sumatera, selatan Pulau Jawa, selatan Pulau Bali, selatan Sumbawa, selatan dan utara Flores, pulaupulau di Maluku Utara, sebagian di selatan Papua, dan utara Pulau Sulawesi.

Disamping itu, banyak diantara wilayah pesisir Indonesia menghadapi permasalahan lingkunganyang serius, seperti banjir rob, abrasi, dan penyusupan air asin ke arah daratan, berbagai masalah pencemaran lingkungan akibat kegiatan industri yang tidak mengelola limbahnya secara baik, selain juga tenggelamnya beberapa pulau kecil, sebagai akibat naiknya permukaan laut dan dampak berbagai kegiatan, antara lain penambangan pasir laut.

Tsunami merupakan salah satu resiko ikutan gempa yang sangat ditakuti oleh umat manusia. Pengalaman gempa yang disusul dengan tsunami pada 26 Desember 2004, dan telah memakan korban jiwa dan harta benda yang luar biasa menyebabkan bangsa Indonesia trauma dengan tsunami. Diposaptono dan Budiman (2005), menyatakan bahwa secara harfiah, tsunami berasal dari bahasa Jepang "tsu" (pelabuhan) dan "nami" (gelombang). Secara umum tsunami diartikan sebagai pasang laut yang besar di pelabuhan. Diposaptono dan Budiman (2005) mendefinisikan tsunami sebagai gelombang laut, dengan periode panjang yang ditimbulkan oleh gangguan impulsif (dapat berupa gempa bumi tektonik, erupsi vulkanik, atau longsoran) yang terjadi melalui media laut.

Kejadian bencana selalu menimbulkan banyak kerugian baik jiwa maupun materi, karena kurangnya kewaspadaan dan kesiapan masyarakat dalam menghadapi ancaman bahaya. Bencana gempa bumi yang terjadi disertai dengan tsunami mengakibatkan wilayah pesisir rusak. Di lain sisi, wilayah pesisir Indonesia termasuk padat dengan permukiman dan pembangunan. Sebagian besar kota-kota penting di Indonesia pun terletak di wilayah pesisir. Oleh karena itu upaya untuk mengurangi atau meminimalisasi dampak yang ditimbulkan oleh tsunami mengingat sifat merusak yang sangat besar menjadi sangat penting. Upaya yang dapat dilakukan adalah 1) mencegah perkembangan permukiman di wilayah pesisir, yang berbatasan langsung dengan laut. Berkenaan dengan hal ini maka pemerintah harus mempersiapkan model tata ruang yang memasukkan unsur resiko tsunami, 2) membuat zona penyangga, dengan tanaman mangrove ataupun tanaman pantai lainnya seperti cemara pantai (Casuarina equisefolia), nyamplung (Calophyllum sp.), dan ketapang (Terminalia catappa).

Pulau Lombok merupakaa salah satu pulau terbesar di Provinsi Nusa Tenggara Barat (NTB) juga memiliki tingkat kerawanan yang tinggi terhadap bencana tsunami. Hal ini dikarenakan bagian selatan Pulau Lombok berhadapan langsung dengan Samudra Hindia yang merupakan pertemuan dua lempeng benua yaitu lempeng Benua Asia dan lempeng Benua Australia (Gambar 1). Kejadian tsunami di daerah Lunyuk Sumbawa bagian selatan pada tahun 1979 juga berdampak pada daerah-daerah selatan Pulau Lombok yaitu daerah kawasan teluk Tanjung Luar di Kecamatan Keruak dan daerah kawasan Teluk Awang di Lombok Tengah. Untuk mencegah terjadinya banyak korban jiwa akibat tsunami ini maka diperlukan upaya pelestarian hutan mangrove yang banyak tumbuh diwilayah pesisir pulau lombok.

Hutan mangrove, dalam skala ekologis merupakan ekosistem yang sangat penting, terutama karena daya dukungnya bagi stabilitas ekosistem kawasan pesisir. Kestabilan ekosistem mangrove akan mempunyai pengaruh yang sangat luas terhadap kelestarian wilayah pesisir. Mangrove sebagai ekosistem hutan, memiliki sifat dan ciri yang sangat khas, tumbuh pada pantai berlumpur dan muara sungai.

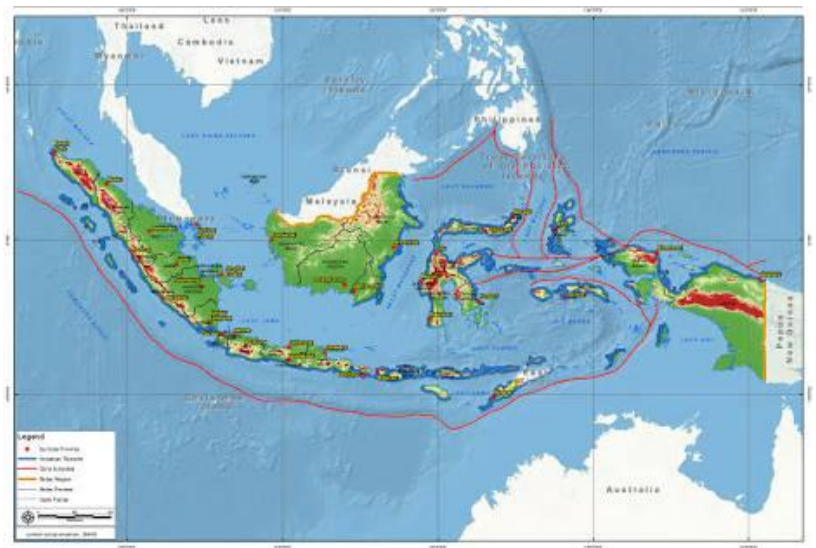

Gambar 1. Peta daerah rawan tsunami di Indonesia

Di lain pihak, ekosistem ini mengalami berbagai tekanan yang sangat berat akibat perluasan dari berbagai keinginan pemanfaatan lainnya. 
Seringkali pemikiran pemanfaatannya hanya didasarkan atas evaluasi ekonomi yang sempit, yang hanya terfokus pada satu penggunaan mangrove. Padahal jika dikaji secara luas, ekosistem mangrove memiliki fungsi dan peran yang sangat kompleks, yang meliputi fungsi ekologis, sosial, dan ekonomi.

Dalam rangka mengurangi bahaya tsunami, dan sekaligus untuk melindungi wilayah pesisir dari ancaman abrasi, angin laut, penyusupan air asin ke arah daratan, menyerap bahan pencemar, serta mempertahankan produktivitas pantai dan laut, perlu dibuat zona perlindungan wilayah pesisir dengan pembangunan hutan mangrove ataupun hutan pantai. Peran hutan mangrove bagi stabilitas wilayah pesisir, semakin kuat dibahas setelah terjadi tsunami 26 Desember 2004. Banyak kalangan semakin menyadari akan pentingnya hutan mangrove sebagai pelindung wilayah pesisir dari berbagai ancaman bencana alam, termasuk tsunami.

Secara sosial, hutan mangrove juga dapatmelestarikan adanya keterkaitan hubungan sosial dengan masyarakat setempat. Karena banyak di antara mereka yang membutuhkan mangrove sebagai tempat mencari ikan, kepiting, udang, maupun mendapatkan kayu dan bahan untuk obatobatan. Di samping itu secara ekonomi, hutan mangrove secara luas akan dapat melindungi nilai ekonomi maritim (Alikodra, 2002). Karena kemampuannya sebagai tempat berpijah berbagai jenis ikan dan udang komersial, ataupun habitat kepiting bakau.

Pengelolaan bencana merupakan salah satu bagian dari pembangunan nasional dalam serangkaian kegiatan baik sebelum, pada saat maupun sesudah terjadinya bencana. Undangundang Nomor 27 Tahun 2007 mengamanatkan bahwa dalam menghadapi ancaman bencana di wilayah pesisir dan pulau-pulau kecil dilakukan upaya mitigasi bencana. Mitigasi bencana adalah upaya untuk mengurangi risiko bencana, baik secara struktur atau fisik melalui pembangunan fisik alami dan/atau buatan maupun nonstruktur atau nonfisik melalui peningkatan kemampuan menghadapi ancaman bencana di wilayah pesisir dan pulau-pulau kecil (Pasal 1 PP No 64 tahun 2010). Mitigasi bencana di wilayah pesisir dan ppk dilakukan melalui kegiatan: a). struktur fisik dan b). nonstruktur/non fisik (Pasal 14 PP No. 64 tahun 2010). Kegiatan struktur/ fisik untuk mitigasi terhadap jenis bencana tsunami meliputi: a) penyediaan sistem peringatan dini dalam penelitian ini dilakukan dengan vegetasi pantai seperti ekosistem mangrove.b) penggunaan bangunan peredam tsunami, c) penyediaan fasilitas penyelamatan diri, d) penggunaan konstruksi bangunan ramah bencana tsunami, e) penyediaan prasarana dan sarana kesehatan, f) vegetasi pantai dan g) pengelolaan ekosistem pesisir (ayat 2 Pasal 15 PP No 64 tahun 2010).

Menyikapi Pasal 15 No 64 tahun 2010 dalam ayat 2 huruf $\mathrm{f}$ usaha mitigasi yang dilakukan di daerah pengabdian menitik beratkan pada ekosistem mangrove dalam mereduksi tsunami. Tsunami dapat direduksi dengan ekosistem mangrove dengan cara menanam sabuk hijau (green belt) (Coachard et al. 2008). Mangrove tanaman yang banyak dijumpai di pantai-pantai daerah tropik dan dapat hidup pada kondisi air payau, salinitas tinggi, dan pasir lumpur. Mangrove yang tumbuh pada substrat yang memiliki bagian dasarnya lempung dapat mereduksi gelombang tsunami, disamping itu juga kepadatan vegetasi mangrove tersebut yang terdiri dari batang, cabang dan akar, contoh mangrove spesies Kandelia candel (Quartel 2007).

Faktor yang menentukan mangrove dapat mereduksi tsunami meliputi: lebar

hutan, kemiringan hutan, kerapatan pohon, diameter pohon, proporsi biomassa di atas permukaan tanah yang terdapat di akar, tinggi pohon, tekstur tanah, lokasi hutan, tipe vegetasi dataran rendah yang berdekatan dengan vegetasi mangrove, keberadaan habitat tepi pantai (padang rumput padang lamun, terumbu karang, bukit), ukuran dan kecepatan tsunami, jarak dari kejadian tektonik, dan sudut datang tsunami yang relatif terhadap garis pantai (Alongi 2005).

Kegiatan pengabdian pada masyarakat Penyuluhan Tentang Mitigasi Bencana Tsunami Berbasis Hutan Mangrove Di Desa Ketapang Raya Kecamatan Keruak Lombok Timur dengan tujuan untuk meningkatkan pemahaman masyarakat khususnya masyarakat Desa Ketapang Raya tentang pentingnya melestarikan hutan mangrove untuk meminimalisir dampak bencana tsunami di wilayah pesisir.

Manfaat dari kegiatan ini adalah tersosialisanya fungsi hutan mangrove untuk mereduksi gelombang tsunami diwilayah pesisir dan agar masyarakat 
wilayah pesisir dapat menjaga kelestarian hutan mangrove diwilayah mereka.

\section{Metode Pelaksanaan}

Pelaksanaan kegiatan pengabdian pada masyarakat ini diawali dengan sosialisasi kegiatan pada aparat pemerintahan yaitu Kepala Desa, Kepala Dusun dan Ketua RT. Sosialisasi berikutnya dilakukan pada masyarakat sasaran. Sosialisasi ini dilakukan oleh ketua dan seluruh anggota tim pelaksana kegiatan.

Penyampaian materi penyuluhan tentang mitigasi bencana tsunami berbasis hutan mangrove dilakukan dengan metode ceramah yang diikuti oleh 50 orang warga masyarakat Desa Ketapang Raya Kabupaten Lombok Timur. Pada saat ini tim menyampaikan materi tentang apa itu mangrove, fungsi dan manfaat hutan mangrove, apa itu tsunami, bagaimana tsunami dapat terjadi, dan bagaimana meminimalisir korban jiwa akibat gelombang tsunami. Metode diskusi dan tanya jawab selanjutnya digunakan untuk lebih memberikan pemahaman kepada masyarakat tentang fungsi hutan mangrove khususnya fungsinya yang dapat meredam laju gelombang tsunami.

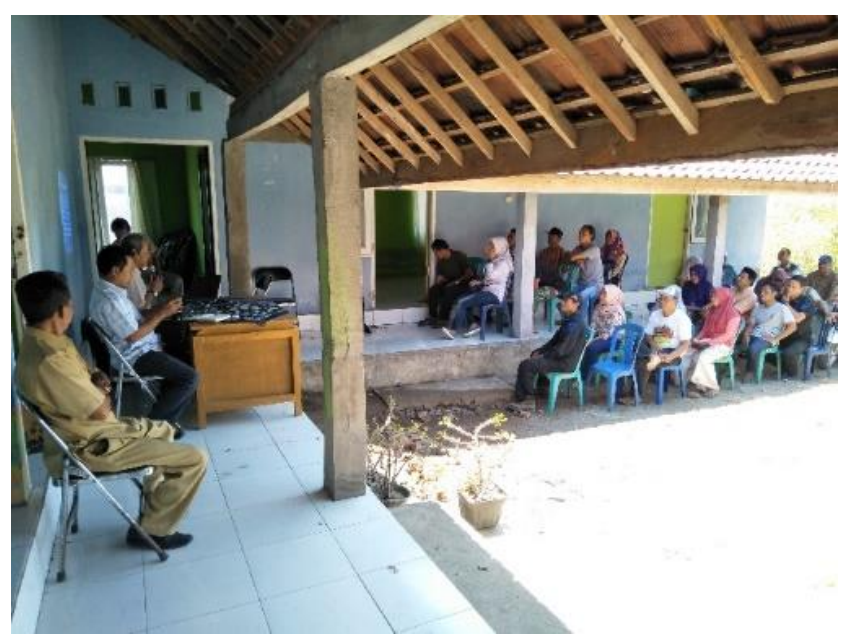

Gambar 2 Suasana saat sosialisasi kegiatan pengabdian di Kantor Desa Ketapang Raya

\section{Kesimpulan}

Dari seluruh rangkaian kegiatan mulai dari sosialisasi sampai pelaksanaan kegiatan dapat disimpulkan bahwa: 1) Sampai saat sekarang ini

\section{Hasil Dan Pembahasan}

Penyuluhan tentang mitigasi bencana tsunami berbasis hutan mangrove bertujuan untuk meningkatkan pemahaman masyarakat khususnya masyarakat Desa Ketapang Raya tentang pentingnya melestarikan hutan mangrove untuk meminimalisir dampak bencana tsunami di wilayah pesisir.

Pada saat pelaksanaan kegiatan, antusiasme masyarakat sasaran sangat tinggi, hal ini dapat dilihat dari banyaknya pertanyaan yang diajukan peserta yang terkait dengan materi yang disampaikan tim pelaksana pada saat diskusi. Kegiatan pengabdian seperti ini sangat penting artinya bagi masyarakat sasaran kerana melalui kegiatan ini mereka dapat memahami akan pentingnya menjaga sumberdaya alam yang ada dilingkungan mereka seperti hutan mangrove. Masyarakat juga disadarkan tentang apa dan bagaimana dapat terjadi, sehingga mereka tidak percaya begitu saja jika ada berita tentang ramalan tsunami akan terjadi diwilayah mereka.

Selanjutnya diharapkan kepada masyarakat yang hadir dalam penyuluhan tersebut dapat menyebarkan kepada masyarakat lainnya tentang pentingnya menjaga kelestarian hutan mangrove dan tentang bagaimana gelombang tsunami terjadi.

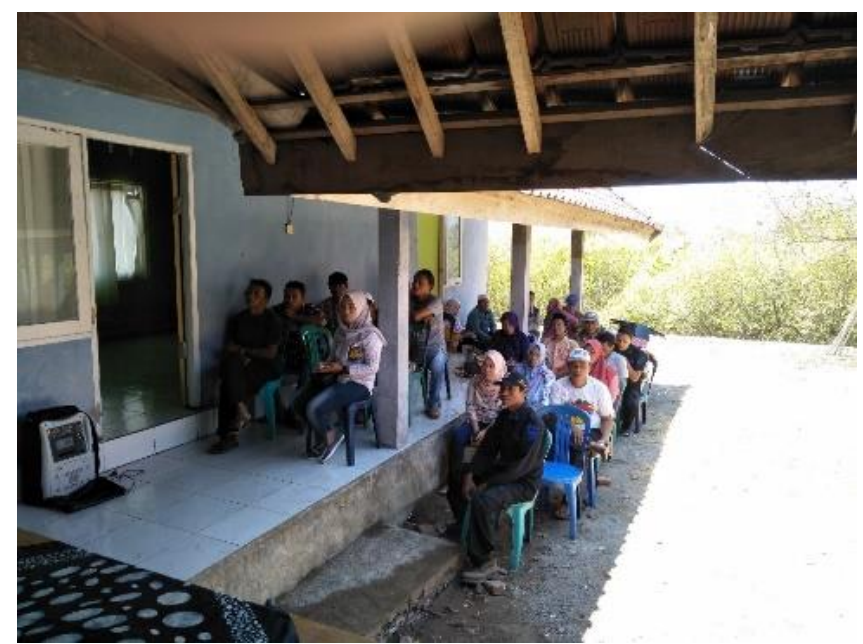

masyarakat Desa Ketapang Raya belum mengetahui akan arti pentingnya keberadaan hutan mangrove di wilayah pesisir mereka. 2) Masarakat juga tidak memahami bagaimana tsunami dapat terjadi, mereka banyak mempercayai ramalan- 
ramalan tentang tsunami. 3) Masyarakat Desa Ketapang Raya memiliki respon yang sangat baik terhadap pelaksanaan kegiatan dan berkomitmen untuk melindungi Kawasan hutan mangrove mereka, bahkan mereka berkomitmen untuk menanam kembali Kawasan mangrove yang mulai rusak.

\section{Saran}

Diperlukan adanya kerjasama yang sinergis antara semua pihak terkait seperti perguruan tinggi, instansi pemerintah, lembaga swadaya masyarakat dalam melakukan penyuluhan kepada masyarakat khususnya tentang manfaat hutan mangrove untuk mengurangi dampak gelombang tsunami.

\section{Daftar Pustaka}

Alikodra, H. S. 2002. Potensi Ekonomi Maritim dari Mangrove dan Pengelolaannya. Makalah disampaikan pada Seminar Pembangunan Ekonomi Maritim Indonesia. Dewan Maritim Indonesia. Jakarta. 10 September 2002.

Alongi DM. 2005. Mangrove microbe soil relations. Di dalam: Kristensen, E., Haese, R.R., Kostka, J.E, editor. Interactions between Macro and Micro organisms in Marine Sediments. American Geophysical Union, Washington, D.C. hlm. 85-103.

Coachard R, Senaratne L, Ranamukhaarachchi, Ganesh, P, Shivakoti, Oleg V Shipin, Peter K Edwards, Klaus T Seeland. 2008. The 2004 tsunami in Aceh and Southern Thailand: A riew on coastal ecosystem, wave hazards and vulnerabiliry. Plant Ecology, Evolution and Systematics 2008; 10:340.

Diposaptono, S. dan Budiman. 2005. Tsunami. Bogor: Penerbit Buku Ilmiah Populer.

Diposaptono, S. 2014. Rencana Zonasi Wilayah Pesisir dan Pulau-Pulau kecil (RZWP3K) / Rencana Tata Ruang Berbasis Mitigasi Bencana. Yogyakarta: Direktorat TataRuang Laut, Pesisir, dan Pulau-Pulau Kecil, Direktorat Jenderal Kelautan, Pesisir, dan Pulau-Pulau Kecil, Kementerian Kelautan dan Perikanan.
Quartel S, A Kroon, PGEF Augustinus, P Van Santen, NH Tri. 2007. Wave Atenuation in Coastal Mangroves in the Red River Delta, Vietnam.Journal of Asian Earth Science 29 (4): 576-584. 